\title{
Inhibitory Actions of Lagerstroemia speciosa (L.) Pers. Aqueous and Ethanolic Leaf Extracts against Carbohydrate-digesting Enzymes
}

\author{
Wanwisa Khunawattanakul, Passakorn Boonma, Ronnarit Kampetch, Achida Jaruchotikamol, \\ Benjamart Cushnie, Sakulrat Rattanakiat, Pawitra Pulbutr*
}

\section{Wanwisa Khunnawat- tanakul, Passakorn Boon- ma, Ronnarit Kampetch, Achida Jaruchotikamol, Benjamart Cushnie, Sakulrat Rattanakiat, Pawitra Pulbutr*}

Pharmaceutical Chemistry and Natural Product Research Unit, Faculty of Pharmacy, Mahasarakham University, Maha Sarakham, 44150, THAILAND.

Correspondence

\section{Dr. Pawitra Pulbutr}

Faculty of Pharmacy Mahasarakham University, Maha Sarakham, 44150, THAILAND.

Phone no : +66-043-754-360

E-mail: pawitra.p@msu.ac.th

\section{History}

- Submission Date: 25-06-2018;

- Review completed: 07-08-2018;

- Accepted Date: 28-09-2018

DOI : 10.5530/pj.2018.6s.22

Article Available online

http://www.phcogj.com/v10/i6s

\section{Copyright}

(C) 2018 Phcog.Net. This is an openaccess article distributed under the terms of the Creative Commons Attribution 4.0 International license.

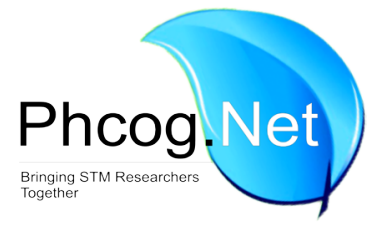

\begin{abstract}
Context: The leaves of Lagerstroemia speciosa (L.) Pers. (banaba) have been consumed traditionally in several Southeast Asian countries for the treatment of diabetes mellitus. The plasma glucose lowering actions of this medicinal plant were proposed to be linked with several mechanisms of action. However, its inhibitory actions against $\alpha$-amylase and $\alpha$-glucosidase, which play a major role in the regulation of postprandial plasma glucose, have not been clearly established. Aims: This study thus aimed to investigate the effects of Lagerstroemia speciosa (L.) Pers. aqueous and ethanolic leaf extracts (LSA and LSE extracts, respectively) on in vitro carbohydrate-digesting enzyme activities and enzyme kinetics. Settings and Design: In vitro carbohydrate-digesting enzyme activity assay. Materials and Methods: The activities of $\alpha$-amylase and $\alpha$-glucosidase were indicated by the amounts of maltose and $p$-nitrophenol generated in the reactions, respectively. Statistical analysis used: The data were analysed by using one-way ANOVA, followed by Bonferroni post-hoc test. Results: The LSA extract significantly inhibited both $\alpha$-amylase and $\alpha$-glucosidase enzymes with the $I C_{50 \text { s }}$ of $1.21 \pm 0.16$ and $49.71 \pm 0.86 \mu \mathrm{g} / \mathrm{mL}$, respectively. Meanwhile, the LSE extract selectively inhibited $\alpha$-amylase activity $\left(I \mathrm{C}_{50}=22.21 \pm 4.00 \mu \mathrm{g} / \mathrm{mL}\right.$ ) with no apparent inhibition against $\alpha$-glucosidase activity. Both LSA and LSE extracts inhibited $\alpha$-amylase enzyme in a mixed inhibition manner whilst the LSA extract also acted as a mixed inhibitor against $\alpha$-glucosidase enzyme. The extracts possessed higher binding affinities toward the enzymes, indicated by the lower $K_{i}$ values, when compared to acarbose (positive control). Conclusion: These results suggest the potential use of the extracts for a control of postprandial plasma glucose.
\end{abstract}

Key words: Lagerstroemia speciosa (L.) Pers., Diabetes mellitus, $\alpha$-amylase, $\alpha$-glucosidase.

\section{INTRODUCTION}

Diabetes mellitus (DM) characterized by chronic hyperglycemia is a leading cause of several life-threatening complications especially cardiovascular diseases, renal failure, blindness and limb amputation. ${ }^{1}$ In diabetic patients, not only fasting plasma glucose but also postprandial plasma glucose must be controlled appropriately in order to prevent diabetic complications. ${ }^{2}$ It has been demonstrated that postprandial hyperglycemia is linked with cardiovascular complications, which are the major cause of death in patients with diabetes. ${ }^{3}$ Carbohydrate-digesting enzymes in the gastrointestinal tract, specifically $\alpha$-amylase and $\alpha$-glucosidase, play a crucial role for the digestion of consumed carbohydrate. Inhibitions against those enzymes are thus the main strategy for controlling postprandial plasma glucose. ${ }^{4}$ The traditional use of medicinal plants has been adopted increasingly worldwide as an alternative treatment of diabetes. Lagerstroemia speciosa (L.) Pers. (banaba) is a medicinal plant widely used for the treatment of diabetes in several South East Asian coun- tries, especially in the Philippines and Thailand, specifically in the central and the Southern parts of the country. Its leaves are consumed as herbal tea, which is prepared by decoction or infusion with hot water, in the traditional medicine. The aqueous and ethanolic leaf extracts of Lagerstroemia speciosa (L.) Pers. significantly reduced the plasma glucose levels in both KK- $\mathrm{A}^{\mathrm{Y}}$ mice and chemical-induced diabetic rats. ${ }^{6-9}$ The hot water leaf extract exhibited the plasma glucose lowering actions in the oral starch tolerance test but not the oral glucose tolerance test in rats. ${ }^{10}$ In vitro inhibitory actions of the leaf extracts of Lagerstroemia speciosa (L.) Pers. against carbohydrate-digesting enzymes were documented previously. ${ }^{10-13}$ However, in most of the earlier studies, the extracts were prepared by using methanol, acetone or ethyl acetate, as the extraction solvents. The methods of extraction were therefore apparently different from its traditional use. Moreover, the effects of the plant extracts on enzyme kinetics

Cite this article: Khunawattanakul W, Boonma P, Kampetch R, Jaruchotikamol A, Cushnie B, Rattanakiat S, Pulbutr P. Inhibitory Actions of Lagerstroemia speciosa (L.) Pers. Aqueous and Ethanolic Leaf Extracts against Carbohydrate-digesting Enzymes. Pharmacog J. 2018;10(6) Suppl:s113-s118. 
of carbohydrate-digesting enzymes have not been described yet. This study thus aimed to investigate the effects of Lagerstroemia speciosa (L.) Pers. aqueous and ethanolic leaf extracts on in vitro a-amylase and a-glucosidase activities. Additionally, the enzyme kinetics of both carbohydrate-digesting enzymes in the presence of the plant extracts were also studied.

\section{MATERIALS AND METHODS}

Preparations of Lagerstroemia speciosa (L.) Pers. aqueous leaf extract (LSA extract) and Lagerstroemia speciosa (L.) Pers. ethanolic leaf extract (LSE extract)

The leaves of Lagerstroemia speciosa (L.) Pers. were collected from the plants in Mahasarakham University, Kamriang campus, Kantarawichai district in Maha Sarakham province, Thailand. Assistant Professor Dr. Wanida Caichompoo, a botanist at the faculty of Pharmacy, Mahasarakham University, performed the authentication of the collected samples. A voucher is deposited at the Herbarium of Pharmaceutical Chemistry and Natural Product Research Unit, the faculty of Pharmacy, Mahasarakham University (code: MSU.PH-LYT-LS01). The leaves were washed thoroughly with tap water, air-dried at room temperature and cut into small pieces. The specimens were then sun-dried for further 2 days and subsequently ground. For the LSA extract, the ground samples were boiled for $15 \mathrm{~min}$, filtered twice with filter cloth and subsequently evaporated by using the freeze dryer (ScanVac, Denmark). For the LSE extract, the specimens were macerated with $70 \%$ ethanol for 7 days and filtered twice with filter cloth. The filtrate was concentrated by using the rotary evaporator (Heidolph ${ }^{\circledR}$, Germany) and then evaporated by using the freeze dryer (ScanVac, Denmark). The \% yields of the LSA and the LSE extracts were 8.77 and $5.08 \% \mathrm{w} / \mathrm{w}$, respectively. The extracts were kept freezing at $-20^{\circ} \mathrm{C}$ until use.

\section{Total phenolic content assay}

The total phenolic content was determined by using the method of Shui et al. ${ }^{14}$ The sample mixture was prepared at the concentration of $50 \mathrm{mg} /$ $\mathrm{mL}$. An aliquot of the sample mixture $(400 \mu \mathrm{L})$ was mixed with $1,800 \mu \mathrm{L}$ of Folin-Ciocalteu (diluted with deionized water, 1:10) and left for $5 \mathrm{~min} .1,200 \mu \mathrm{L}$ of $\mathrm{Na}_{2} \mathrm{CO}_{3}(7.5 \% \mathrm{w} / \mathrm{v})$ was then added, mixed well and incubated at room temperature for 1 hour. The optical density (OD) of the mixture was measured at the wavelength of $765 \mathrm{~nm}$. The standard solutions with varying concentrations of gallic acid were prepared in methanol. The total phenolic content was calculated from the gallic acid standard curve and expressed as mg of gallic acid equivalent (GAE)/ g of extract (dry weight).

\section{Total flavonoid content assay}

The total flavonoid content assay was performed by using the assay described by Pekal and Pyrzynska, 2014. ${ }^{15} 300 \mu \mathrm{L}$ of $\mathrm{AlCl}_{3}(2 \% \mathrm{w} / \mathrm{v})$ and $300 \mu \mathrm{L}$ of deionized water were added into $600 \mu \mathrm{L}$ of the sample mixture $(10 \mathrm{mg} / \mathrm{mL})$. The mixture was shaken well and left for $10 \mathrm{~min}$. The OD of the mixture was measured at the wavelength of $425 \mathrm{~nm}$. The total flavonoid content was calculated from the quercetin standard curve and expressed as mg of quercetin equivalent $(\mathrm{QE}) / \mathrm{g}$ of extract (dry weight).

\section{Alpha-amylase activity assay}

The $\alpha$-amylase activity assay was performed according to the method of Ali et al. with slight modifications. ${ }^{16}$ Briefly, $40 \mu \mathrm{L}$ of the sample was pre-incubated with $200 \mu \mathrm{L}$ of porcine pancreatic $\alpha$-amylase ( $4 \mathrm{unit} / \mathrm{mL}$ ) at $25^{\circ} \mathrm{C}$ for $5 \mathrm{~min} .400 \mu \mathrm{L}$ of potato starch solution $(0.5 \% \mathrm{w} / \mathrm{v})$ and $160 \mu \mathrm{L}$ of deionized water were subsequently added into the mixture and incubated at $25^{\circ} \mathrm{C}$ for further $3 \mathrm{~min}$. An aliquot of the mixture $(200 \mu \mathrm{L})$ was then transferred to mix with $100 \mu \mathrm{L}$ of 3,5-dinitrosalicylic acid (DNS) color reagent ( $96 \mathrm{mM}$ DNS and $5.31 \mathrm{M}$ sodium potassium tartrate in $2 \mathrm{M} \mathrm{NaOH}$ ) and then boiled at $85^{\circ} \mathrm{C}$ for $15 \mathrm{~min}$. The OD of the mixture was measured at the wavelength of $540 \mathrm{~nm}$ by using absorbance microplate reader (BMG LABTECH, Germany). The concentration of maltose, generated from $\alpha$-amylase catalyzing reaction, was calculated from the maltose standard curve and used as an index of $\alpha$-amylase activity. Percent reaction was obtained from the following equation: \% reaction $=($ mean maltose in sample/ mean maltose in negative control $) \times 100$. Percent inhibition was calculated as 100 - \% reaction. Acarbose was used as positive control in the experiment. The concentration-inhibitory response curve, the Lineweaver-Burk plot and the rate of reaction $v s$. substrate concentration curve were generated by using GraphPad Prism software version 6.0 . The inhibition constant $\left(\mathrm{K}_{\mathrm{i}}\right)$ was obtained by fitting the rate of reaction $v s$. substrate concentration curve with mixed model inhibition in GraphPad Prism software version 6.0.

\section{Alpha-glucosidase activity assay}

The $\alpha$-glucosidase activity was performed following the protocol of Elya et al. with minor modifications. ${ }^{17}$ In brief, a mixture of the sample $(40 \mu \mathrm{L}), 100 \mathrm{mM}$ phosphate buffer, $\mathrm{pH} 6.8(460 \mu \mathrm{L})$ and 0.15 unit $/ \mathrm{mL}$ yeast $\alpha$-glucosidase enzyme $(125 \mu \mathrm{L})$ was prepared and incubated at $37^{\circ} \mathrm{C}$ for $5 \mathrm{~min} .250 \mu \mathrm{L}$ of $p$-nitrophenyl- $\alpha$-D-glucopyranoside ( $p$-NPG; $5 \mathrm{mM}$ ) and $125 \mu \mathrm{L}$ of phosphate buffer were added into the mixture and incubated for further $15 \mathrm{~min}$ at $37^{\circ} \mathrm{C}$. Subsequently, an aliquot of the mixture $(200 \mu \mathrm{L})$ was mixed with $400 \mu \mathrm{L}$ of $\mathrm{Na}_{2} \mathrm{CO}_{3}(200 \mathrm{mM})$, the solution was then left at room temperature for further $5 \mathrm{~min}$. The OD of the final mixture was measured at the wavelength of $405 \mathrm{~nm}$. The amount of $p$-nitrophenol released from $\alpha$-glucosidase-catalyzing reaction was used as an index of $\alpha$-glucosidase activity. The percentage of inhibition was calculated as the following equation: $\%$ inhibition $=[(\mathrm{OD}$ of negative control) - (OD of sample) / (OD of negative control)] x 100. Acarbose was used as positive control in the experiment. The concentration-inhibitory response curve, the Lineweaver-Burk plot and the rate of reaction vs. substrate concentration curve were plotted by using GraphPad Prism software version 6.0. The inhibition constant $\left(\mathrm{K}_{\mathrm{i}}\right)$ was obtained by fitting the rate of reaction $v s$. substrate concentration curve with mixed model inhibition in GraphPad Prism software version 6.0.

\section{Statistical analysis}

The data of $\%$ inhibition against enzyme activity was expressed as mean \pm SEM, whilst the data of the median inhibitory concentration $\left(\mathrm{IC}_{50}\right)$, the total phenolic content and the total flavonoid content were shown as mean \pm SD. The statistical analysis was performed by using one-way analysis of variance (ANOVA) followed by the Bonferroni post-hoc test. The difference between data is considered statistically significant when a $p$-value is less than 0.05

\section{RESULTS}

The total phenolic content and the total flavonoid content of the LSA and the LSE extracts

The total phenolic content and the total flavonoid content of the extracts are shown in Table 1.

\section{Effects of the LSA and the LSE extracts on in vitro a-amylase activity}

The LSA extract at the concentrations of $0.5,1,3,5$ and $10 \mu \mathrm{g} / \mathrm{mL}$ significantly inhibited $\alpha$-amylase activity with the $\mathrm{IC}_{50}$ of $1.21 \pm 0.16 \mu \mathrm{g} / \mathrm{mL}$ (Table 2). The highest $\%$ inhibition of $55.56 \pm 3.05$ was found at $5 \mu \mathrm{g} / \mathrm{mL}$ of the extract. 
The LSE extract at the concentrations of $10,30,60$ and $100 \mu \mathrm{g} / \mathrm{mL}$ produced a significant inhibitory action against $\alpha$-amylase enzyme with the $\mathrm{IC}_{50}$ of $22.21 \pm 4.00 \mu \mathrm{g} / \mathrm{mL}$. The maximal inhibition of $95.41 \pm 1.78 \%$ was found at $100 \mu \mathrm{g} / \mathrm{mL}$ of the extract (Table 2).

Acarbose (positive control) produced a significant inhibition against $\alpha$-amylase with the $\%$ inhibition of $66.54 \pm 2.12 \%$.

\section{Effects of the LSA and the LSE extracts on a-amylase enzyme kinetics}

From the Lineweaver-Burk plot, both LSA and LSE extracts at their approximate $\mathrm{IC}_{50 \mathrm{~s}}$ (1 and $20 \mu \mathrm{g} / \mathrm{mL}$, respectively) caused changes in the $\alpha$-amylase enzyme kinetics (Figure 1, Table 3 ). Both extracts decreased $\mathrm{V}_{\max }$, but increased $\mathrm{K}_{\mathrm{m}}$ of the $\alpha$-amylase enzyme kinetics. Acarbose $(100 \mu \mathrm{g} / \mathrm{mL})$ also caused a similar change in enzyme kinetics as that of the extracts.

The rates of reaction (v) were determined at various concentrations of the substrate (starch solution) in the presence or absence of the inhibitors (the LSA extract, the LSE extract or acarbose) at several concentrations (Figure 2). The inhibition constants $\left(\mathrm{K}_{\mathrm{i}}\right)$ of the inhibitors against $\alpha$-amylase are shown in Table 3 .

\section{Effects of the LSA and the LSE extracts on in vitro a-glucosidase activity}

The LSA extract at every concentration tested significantly inhibited $\alpha$-glucosidase enzyme activity with the $\mathrm{IC}_{50}$ of $49.71 \pm 0.86 \mu \mathrm{g} / \mathrm{mL}$ (Table 4 ). The LSE extract produced a slight and non-significant inhibition against $\alpha$-glucosidase enzyme (Table 4 ). Thus, the $\mathrm{IC}_{50}$ of the LSE extract against $\alpha$-glucosidase could not be determined.

Acarbose at the concentration of $200 \mu \mathrm{g} / \mathrm{mL}$ had a significant inhibition against $\alpha$-glucosidase with the $\%$ inhibition of $39.59 \pm 1.21 \%$.

Table 1: The total phenolic content and the total flavonoid content of the LSA and the LSE extracts.

\begin{tabular}{ccc}
\hline Extracts & $\begin{array}{c}\text { Total phenolic content } \\
\text { (mg of GAE/ } \mathrm{g} \text { of extract) }\end{array}$ & $\begin{array}{c}\text { Total flavonoid content } \\
\text { ( } \mathrm{mg} \text { of QE/ } \mathrm{g} \text { of extract) }\end{array}$ \\
\hline LSA extract & $11.56 \pm 0.35^{*}$ & $21.44 \pm 1.11^{*}$ \\
LSE extract & $8.84 \pm 0.13$ & $15.84 \pm 1.00$ \\
\hline
\end{tabular}

${ }^{*} p<0.05$ when compared with the LSE extract; independent sample Student's $t$-test; $\mathrm{n}=5$

Table 2: The percentage of inhibition of the LSA extract and the LSE extract against $\alpha$ - amylase activity.

\begin{tabular}{cccc}
\hline \multicolumn{2}{c}{ LSA extract } & \multicolumn{2}{c}{ LSE extract } \\
\hline $\begin{array}{c}\text { Concentration } \\
(\mu \mathrm{g} / \mathrm{mL})\end{array}$ & $\begin{array}{c}\% \text { inhibition } \\
(\text { mean } \pm \text { SEM) }\end{array}$ & $\begin{array}{c}\text { Concentration } \\
(\mu \mathrm{g} / \mathrm{mL})\end{array}$ & $\begin{array}{c}\% \text { inhibition } \\
(\text { mean } \pm \text { SEM) }\end{array}$ \\
\hline 0 & $0.00 \pm 0.00$ & 0 & $0.97 \pm 0.97$ \\
0.3 & $11.21 \pm 2.36$ & 0.3 & $-1.65 \pm 2.12$ \\
0.5 & $15.57 \pm 3.29^{*}$ & 1 & $0.80 \pm 2.65$ \\
1 & $27.90 \pm 4.67^{*}$ & 10 & $37.83 \pm 5.91^{*}$ \\
3 & $52.12 \pm 3.71^{*}$ & 30 & $71.70 \pm 2.54^{*}$ \\
5 & $55.56 \pm 3.05^{*}$ & 60 & $91.70 \pm 1.94^{*}$ \\
10 & $53.93 \pm 2.59^{*}$ & 100 & $95.41 \pm 1.78^{*}$ \\
\hline
\end{tabular}

${ }^{*} p$-value $<0.05$ when compared with negative control; One-way ANOVA, Bonferroni post-hoc test; $\mathrm{n}=6$

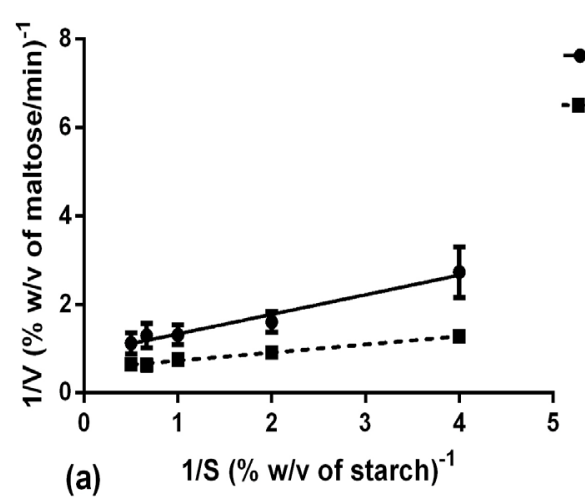

LSA extract

-n. Control
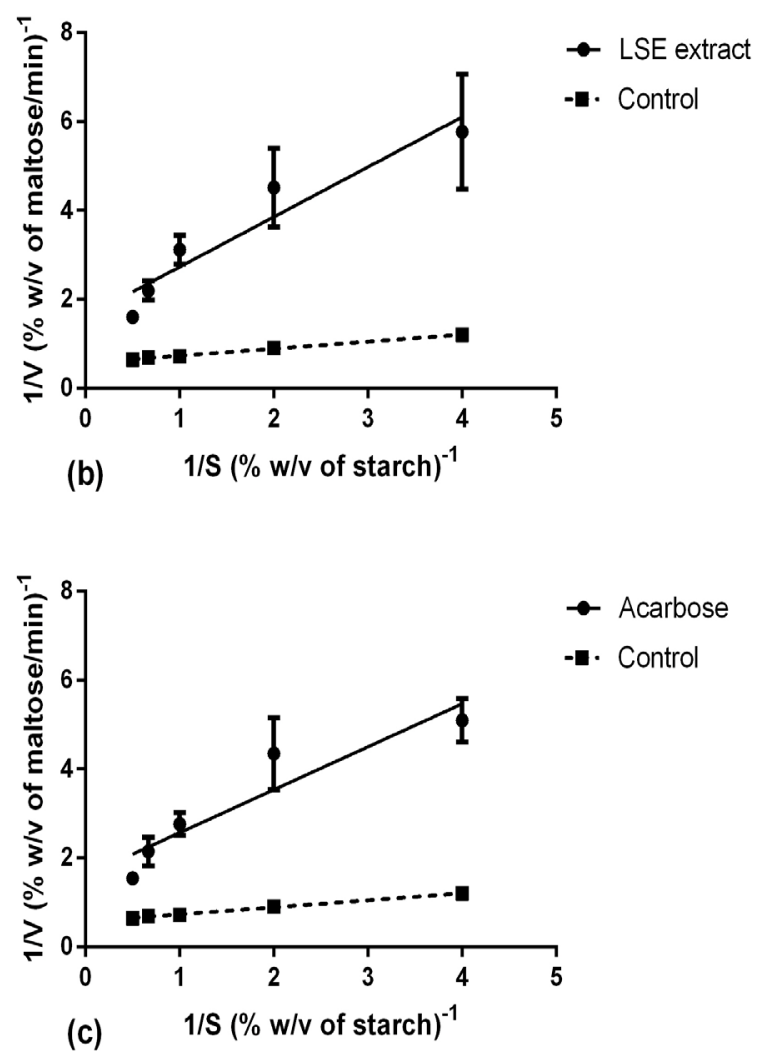

Figure 1: Lineweaver-Burk plots of the a-amylase-catalyzing reaction in the presence or absence of (a) the LSA extract $(1 \mu \mathrm{g} / \mathrm{mL})$, (b) the LSE extract $(20 \mu \mathrm{g} / \mathrm{mL})$ and $(\mathrm{c})$ acarbose $(100 \mu \mathrm{g} / \mathrm{mL})$. (mean $\pm S D, \mathrm{n}=6)$.

Table 3: Enzyme kinetics study and inhibition constant $\left(K_{i}\right)$ of the test agents against $\alpha$-amylase and $a$-glucosidase.

\begin{tabular}{ccccccc}
\hline \multicolumn{1}{c}{ Agents } & \multicolumn{3}{c}{$\mathrm{a}$-amylase } & \multicolumn{3}{c}{$\mathrm{a}$-glucosidase } \\
\hline & $\Delta \mathrm{V}_{\max }$ & $\Delta \mathrm{K}_{\mathrm{m}}$ & $\mathrm{K}_{\mathrm{i}}$ & $\Delta \mathrm{V}_{\max }$ & $\Delta \mathrm{K}_{\mathrm{m}}$ & $\mathrm{K}_{\mathrm{i}}$ \\
\hline LSA extract & -0.72 & +0.16 & 6.26 & -0.34 & +0.01 & 42.24 \\
LSE extract & -1.12 & +0.43 & 3.01 & $\mathrm{n} / \mathrm{d}$ & $\mathrm{n} / \mathrm{d}$ & $\mathrm{n} / \mathrm{d}$ \\
Acarbose & -1.12 & +0.33 & 12.43 & -0.03 & +0.33 & 47.24 \\
\hline
\end{tabular}

$\mathrm{n} / \mathrm{d}=$ The data was not determined. 


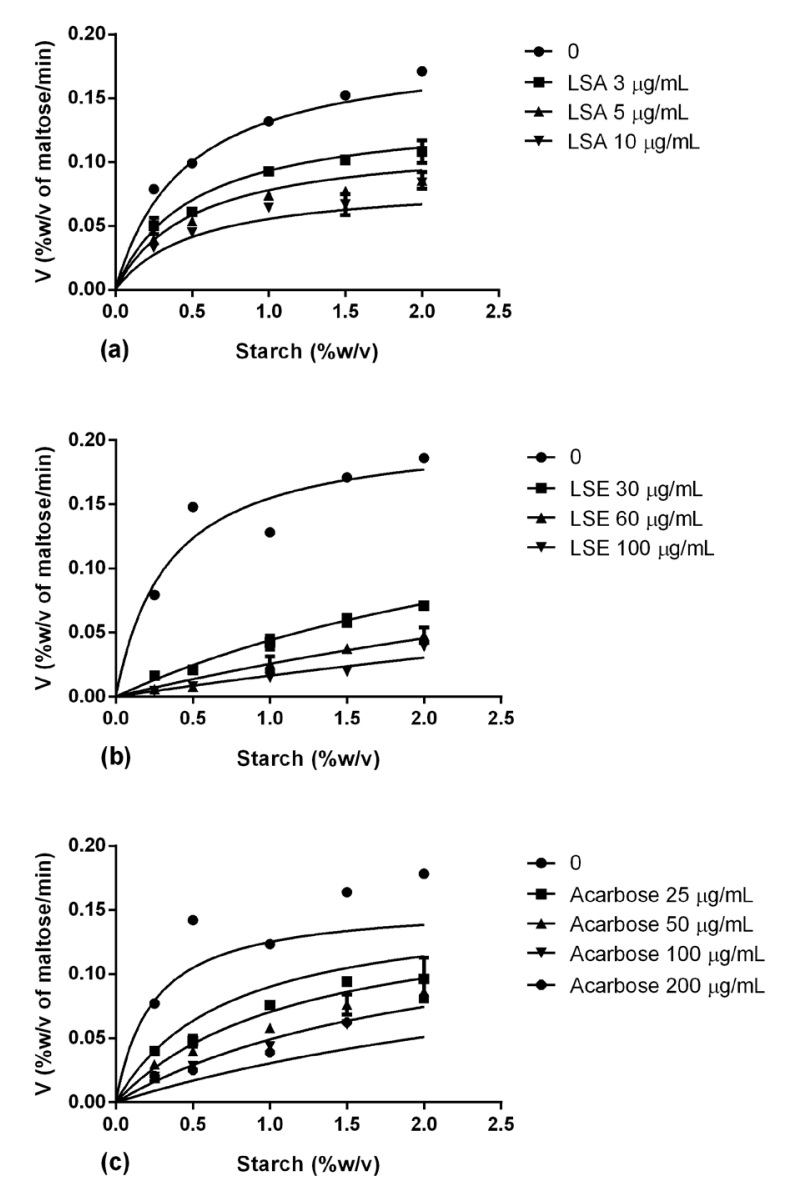

Figure 2: The rate of reaction vs. substrate concentration curve in the presence of several concentrations of the inhibitors ((a) the LSA extract, (b) the LSE extract and (c) acarbose) against a-amylase activity. (mean $\pm S D, n=3$ )

Table 4: The percentage of inhibition of the LSA extract and the LSE extract against a-glucosidase activity.

\begin{tabular}{ccc}
\hline Concentration $(\mu \mathrm{g} / \mathrm{mL})$ & \% inhibition $($ mean \pm SEM) & \\
\cline { 2 - 3 } & LSA extract & LSE extract \\
\hline 0 & $0.00 \pm 0.00$ & $0.00 \pm 0.00$ \\
3 & $12.07 \pm 2.45^{*}$ & $10.82 \pm 1.41$ \\
10 & $15.54 \pm 1.95^{*}$ & $16.41 \pm 3.29$ \\
30 & $22.90 \pm 3.27^{*}$ & $9.77 \pm 3.06$ \\
50 & $48.93 \pm 1.37^{*}$ & $7.91 \pm 2.67$ \\
100 & $68.26 \pm 0.98^{*}$ & $9.04 \pm 3.90$ \\
300 & $65.63 \pm 1.69^{*}$ & $8.06 \pm 2.07$ \\
\hline
\end{tabular}

${ }^{*} p$-value $<0.05$ when compared with negative control; One-way ANOVA, Bonferroni post-hoc test; $\mathrm{n}=3$

\section{Effects of the LSA extract on a-glucosidase enzyme kinetics}

The LSA extract at the concentration of $50 \mu \mathrm{g} / \mathrm{mL}$ (approximate $\mathrm{IC}_{50}$ ) produced a decrease in $\mathrm{V}_{\max }$ and a trivial increase in $\mathrm{K}_{\mathrm{m}}$ from the Line-
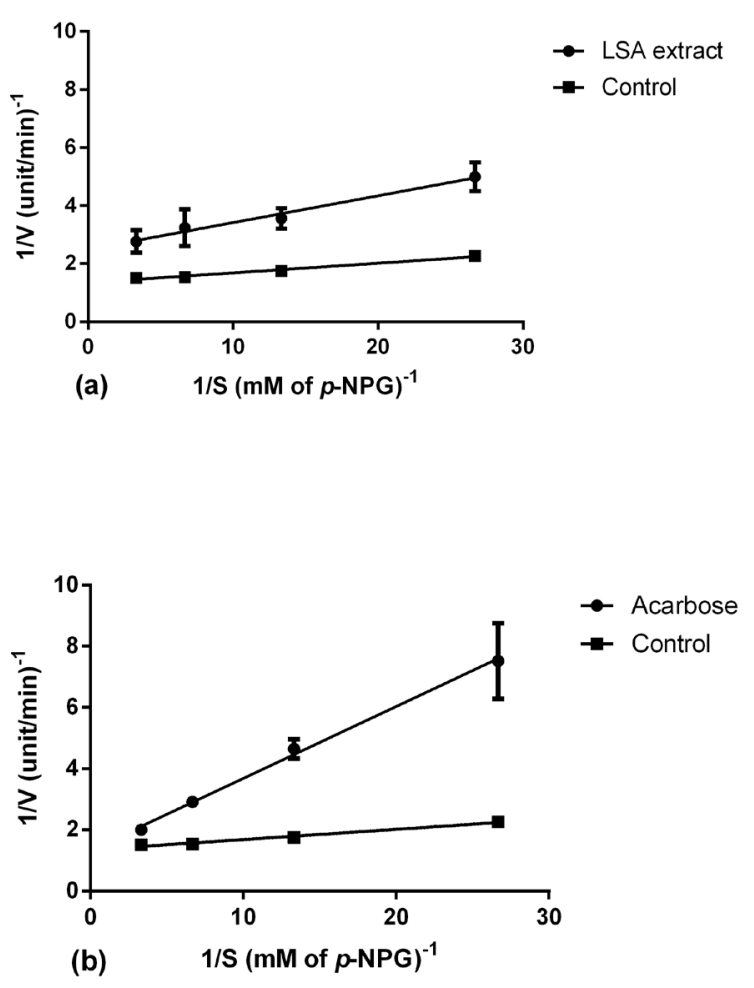

Figure 3: Lineweaver-Burk plots of the a-glucosidase-catalyzing reaction in the presence or absence of (a) the LSA extract $(50 \mu \mathrm{g} / \mathrm{mL})$ and (b) acarbose $(200 \mu \mathrm{g} / \mathrm{mL})$. (mean $\pm S D, n=6)$.

weaver-Burk plot (Figure 3, Table 3). Meanwhile, acarbose $(200 \mu \mathrm{g} / \mathrm{mL})$ changed the $\alpha$-glucosidase enzyme kinetics with an increase in $\mathrm{K}_{\mathrm{m}}$ and a slight decrease in $\mathrm{V}_{\max }$.

The rates of reaction (v) were determined at various concentrations of the substrate ( $p$-NPG) in the presence of the inhibitors (the LSA extract or acarbose) at different concentrations (Figure 4). The inhibition constants $\left(\mathrm{K}_{\mathrm{i}}\right)$ of the inhibitors against $\alpha$-glucosidase are shown in Table 3.

\section{DISCUSSION}

The LSA and the LSE extracts produced significant inhibitory actions against $\alpha$-amylase activity with the $\mathrm{IC}_{50 \mathrm{~s}}$ of $1.21 \pm 0.16$ and $22.21 \pm 4.00 \mu \mathrm{g} / \mathrm{mL}$, respectively. The LSA extract also had a significant $\alpha$-glucosidase inhibiting activity with the $\mathrm{IC}_{50}$ of $49.71 \pm 0.86 \mu \mathrm{g} / \mathrm{mL}$. Nonetheless, the LSE extract caused a slight and non-significant inhibition against $\alpha$-glucosidase. The inhibitory potency of the LSA extract against $\alpha$-amylase was thus higher than that of the LSE extract. Additionally, the $\alpha$-amylase inhibitory action of the LSA extract was more potent than its $\alpha$-glucosidase-inhibiting activity. The inhibitory actions against both $\alpha$-amylase and $\alpha$-glucosidase of the hot water extract of Lagerstroemia speciosa (L.) Pers. leaves were demonstrated previously with the higher $\mathrm{IC}_{50 \mathrm{~s}}$ of 530 and $890 \mu \mathrm{g} / \mathrm{mL}$, respectively. ${ }^{10}$ Although the $\mathrm{IC}_{50 \mathrm{~s}}$ of the extracts against carbohydrate-digesting enzymes found in this study are somewhat different from those reported earlier by Suzuki et al. both studies showed the higher potency of the extracts against $\alpha$-amylase over $\alpha$-glucosidase activity. The discrepancy of the $\mathrm{IC}_{50}$ values found between the studies may be due to the differences in plant sources and methods 


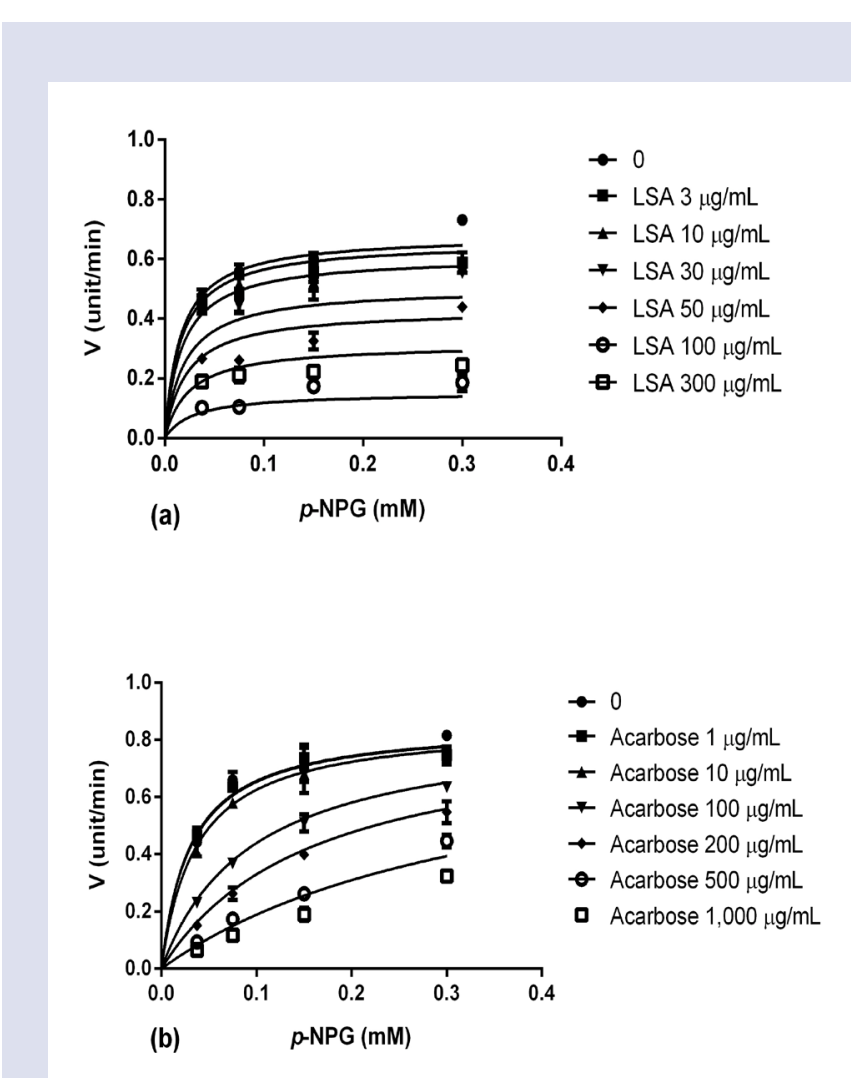

Figure 4: The rate of reaction vs. substrate concentration curve in the presence of several concentrations of the inhibitors ((a) LSA extract and (b) acarbose) against a-glucosidase activity. (mean $\pm S D, n=3$ )

of extraction. The $\alpha$-amylase inhibitory action of the $50 \%$ methanolic extract of Lagerstroemia speciosa (L.) Pers. leaves was reported by Hansawasdi et al. However, the $\mathrm{IC}_{50}$ was not determined in their study. ${ }^{11}$ The acetone extract of the plant leaves was found to possess $\alpha$-amylase inhibitory action with the $\mathrm{IC}_{50}$ of $244 \mu \mathrm{g} / \mathrm{mL} .^{12}$ Meanwhile, the ethyl acetate leaf extract of Lagerstroemia speciosa (L.) Pers. selectively inhibited $\alpha$-glucosidase $\left(\mathrm{IC}_{50}\right.$ of $88.72 \pm 1.02 \mu \mathrm{g} / \mathrm{mL}$ ), without any inhibitory action against $\alpha$-amylase. ${ }^{13}$ Taken together, it is likely that the aqueous extract used in this study possessed more potent inhibitory actions against carbohydrate-digesting enzymes than the other solvent extracts. These are in agreement with the traditional use of the plant leaves as herbal tea, prepared by decoction or infusion with hot water, for the treatment of diabetes mellitus. ${ }^{5}$

Several phytochemical compounds found in Lagerstroemia speciosa (L.) Pers. leaf extracts have been reported to possess $\alpha$-amylase and $\alpha$-glucosidase inhibiting activities. These included triterpene acids (e.g. corosolic acid, oleanolic acid, ursolic acid), flavonoids (e.g. kaempferol, quercetin, isoquercetin), ellagitannins, valoneaic acid dilactone and caffeic acid. ${ }^{12-13,16,18-22}$ Among these active phytochemicals, the phenolic compounds with low octanol-water partition coefficient, which indicates their high hydrophilicity, are isoquercetin, ellagitannins, ellagic acid and caffeic acid. These more polar phytochemicals possibly acted as $\alpha$-amylase and $\alpha$-glucosidase inhibitors in the extracts used in this study since the LSA extract had the higher potency of carbohydratedigesting enzyme inhibition. Consistently, the amounts of TPC and TFC in the LSA extract were significantly higher than those were in the LSE extract. Nonetheless, further studies are required to spec- ify the active phytochemicals acting against carbohydrate-digesting enzymes in the tested extracts. The phytochemical constituents with carbohydrate-digesting enzyme inhibitory actions in several plants including banaba play an essential role as a natural defence mechanism against insect pest. ${ }^{23}$ The enzyme inhibitors suppress food digestion of the insect through their actions against carbohydrate-digesting enzymes. The Lineweaver-Burk plots were generated in order to characterize modes of enzyme inhibition, which indicated by alterations of $\mathrm{V}_{\max }$ and $\mathrm{K}_{\mathrm{m}}$. The $\mathrm{y}$-intercept of the Lineweaver-Burk plot is equivalent to the inverse of $\mathrm{V}_{\max }$, whilst the $\mathrm{x}$-intercept of the plot represents $-1 / \mathrm{K}_{\mathrm{m}}$. From the $\alpha$-amylase enzyme kinetics study, the two extracts and acarbose (positive control) caused similar changes in the enzyme kinetics with a reduction in $\mathrm{V}_{\max }$ but an increase in $\mathrm{K}_{\mathrm{m}}$. This indicated that they inhibited $\alpha$-amylase in a mixed-inhibition manner. Acarbose was also previously described as a mixed inhibitor against $\alpha$-amylase. ${ }^{24-25}$ The degree of changes in $\mathrm{V}_{\max }$ and $\mathrm{K}_{\mathrm{m}}$ caused by the LSE extract was comparable to that modified by acarbose, whereas the LSA extract produced a lower degree of changes in both $\mathrm{V}_{\max }$ and $\mathrm{K}_{\mathrm{m}}$. For the $\alpha$-glucosidase enzyme kinetics, the LSA extract and acarbose (positive control) induced a depletion of $\mathrm{V}_{\max }$ and a rise of $\mathrm{K}_{\mathrm{m}}$. This suggested that the LSA extract and acarbose also inhibited $\alpha$-glucosidase enzyme in a mixed inhibition manner. On the other hand, the competitive inhibition against $\alpha$-glucosidase of acarbose was demonstrated earlier. ${ }^{26}$ Nonetheless, it should be noted that the levels of $\mathrm{K}_{\mathrm{m}}$ increment and $\mathrm{V}_{\max }$ reduction found in this study were only trivial in the presence of the LSA extract and acarbose, respectively. The inhibition constants $\left(\mathrm{K}_{\mathrm{i}}\right)$ of both extracts against $\alpha$-amylase were lower than that of acarbose. Concomitantly, the LSA extract also had a lower K value against $\alpha$-glucosidase than acarbose. Thus, the tested extracts had higher binding affinities toward both carbohydrate-digesting enzymes. This indicated that the enzyme inhibitors in the extracts could bind effectively with the enzymes even when using the low concentration of the extracts.

In the clinical use, an enzyme inhibitor with a mixed mode of inhibition provides some advantages over competitive or non-competitive inhibitors since the rate of carbohydrate digestion is suppressed distinctly even when an increased amount of substrate (carbohydrate) is consumed. When only a low amount of substrate is ingested, the rate of carbohydrate digestion is also markedly diminished in the presence of a mixed enzyme inhibitor. In other words, an inhibitory action of a mixed enzyme inhibitor does not depend on the level of substrate. Furthermore, the LSA extract inhibited both $\alpha$-amylase and $\alpha$-glucosidase activities. This also provides some benefits over an inhibition against each enzyme alone since digestions of various types of carbohydrate (e.g. starch, oligosaccharides and disaccharides), can be restricted in the presence of the extracts with dual enzyme-inhibiting actions.

Lagerstroemia speciosa (L.) Pers. leaf extracts have been shown to produce their plasma glucose-lowering actions via various mechanisms of action such as enhancement of insulin sensitivity, stimulation of cellular glucose uptake and inhibition of hepatic gluconeogenesis. ${ }^{6,27-28}$ The carbohydratedigesting enzyme inhibitory actions of the LSA and the LSE extracts demonstrated in this study thus additionally explain the anti-diabetic mechanisms of the plant and further suggest its potential use for a control of postprandial plasma glucose.

\section{CONCLUSION}

Both LSA and LSE extracts inhibited $\alpha$-amylase enzyme in a mixed inhibition manner. The LSA extract also acted as a mixed inhibitor against $\alpha$-glucosidase enzyme, whilst the LSE extract had no inhibitory action against $\alpha$-glucosidase activity. These results suggest the potential use of the extracts for a control of postprandial plasma glucose. 


\section{ACKNOWLEDGEMENT}

This project was financially supported by Mahasarakham University Research Support and Development Fund (grant number 610104/2561).

\section{CONFLICT OF INTEREST}

The authors declare no conflict of interest.

\section{ABBREVIATIONS}

IC $_{50}$ : median inhibitory concentration; $\mathbf{K}_{\mathrm{m}}$ : Substrate concentration which permits the enzyme to achieve half-maximal rate of reaction; $\mathbf{V}_{\max }$ : maximal rate of reaction.

\section{REFERENCES}

1. WHO [Internet]. Geneva: Diabetes fact sheet. c2017 - [cited 2017 Nov 15]. Available from: http://www.who.int/mediacentre/factsheets/fs312/en/.

2. American Diabetes Association. Standards of Medical care in diabetes. Diabetes Care 2017;40:1-142.

3. Ceriello A, Davidson J, Hanefeld M, Leiter L, Monnier L, Owens D, et al. Postprandial hyperglycaemia and cardiovascular complications of diabetes: An update. Nutr Metab Cardiovasc Dis. 2006;16(7):453-6.

4. Joshi SR, Standl E, Tong N, Shah P, Kalra S, Rathod R. Therapeutic potential of $\alpha$-glucosidase inhibitors in type 2 diabetes mellitus: an evidence-based review. Expert Opin Pharmacother. 2015;16(13):1959-81.

5. Chan EWC, Tan LN, Wong SK. Phytochemistry and pharmacology of Lagerstroemia speciosa: a natural remedy for diabetes. Int J Herb Med. 2014;2(2):100-5.

6. Saha BK, Bhuiyan MNH, Mazumder K, Haque KMF. Hypoglycemic activity of Lagerstroemia speciosa L. extract on streptozotocin-induced diabetic rat: underlying mechanism of action. Bangladesh J Pharmacol. 2009;4(2):79-83.

7. Saumya SM, Basha PM. Antioxidant effect of Lagerstroemia speciosa Pers. (Banaba) leaf extract in streptozotocin-induced diabetic mice. Indian J Exp Biol. 2011;49(2):125-31.

8. Singh LS, Singh NS, Devi MA. Hypoglycaemic effect of Lagerstroemia speciosa in type 2 diabetic rats. J Med Plants Res. 2014;8(25):899-902.

9. Thuppia A, Rabintossaporn P, Saenthaweesuk S, Ingkaninan K. The hypoglycemic effect of water extract from leaves of Lagerstroemia speciosa L. in streptozotocininduced diabetic rats. Songklanakarin J Sci Technol. 2009;31(2):133-7.

10. Suzuki Y, Kazuhiko H, Sakane I, Kakuda T. Effect and mode of action of Banaba (Lagerstroemia speciosa L.) leaf extracts on postprandial blood glucose in rats. J Japan Soc Nutr Food Sci. 2001;54:131-7.

11. Hansawasdi C, Kawabata J, Kasai T. Alpha-amylase inhibitors from Roselle (Hibiscus sabdariffa Linn.) tea. Biosci Biotechnol Biochem. 2000;64(5):1041-3.

12. Hosoyama H, Sugimoto A, Suzuki Y, Sakane I, Kakuda T. Isolation and quantitative analysis of the $\alpha$-amylase inhibitor in Lagerstroemia speciosa (L.) Pers. (Banaba). Yakugaku Zasshi. 2003;123(7):599-605
13. Hou W, Li Y, Zhang Q, Wei X, Peng A, Chen L, et al. Triterpene acids isolated from Lagerstroemia speciosa leaves as alpha-glucosidase inhibitors. Phyther Res. 2009;23(5):614-8.

14. Shui G, Leong LP, Wong SP. Rapid screening and characterisation of antioxidants of Cosmos caudatus using liquid chromatography coupled with mass spectrometry. J Chromatogr B Analyt Technol Biomed Life Sci. 2005:827(1):127-38.

15. Pekal A, Pyrzynska K. Evaluation of aluminium complexation reaction for flavonoid content assay. Food Anal Methods. 2014;7(9):1776-82.

16. Ali $H$, Houghton PJ, Soumyanath A. $\alpha$-Amylase inhibitory activity of some Malaysian plants used to treat diabetes; with particular reference to Phyllanthus amarus. J Ethnopharmacol. 2006;107(3):449-55.

17. Elya B, Basah K, Mun'Im A, Yuliastuti W, Bangun A, Septiana EK. Screening of alpha-glucosidase inhibitory activity from some plants of Apocynaceae, Clusiaceae, Euphorbiaceae and Rubiaceae. J Biomed Biotechnol. 2012. doi:10.1155/2012/281078

18. Li Y, Gao F, Gao F, Shan F, Bian J, Zhao C. Study on the interaction between 3 flavonoid compounds and $\alpha$-amylase by fluorescence spectroscopy and enzymatic kinetics. J Food Sci. 2009;74(3):C199-203.

19. McDougall GJ, Shpiro F, Dobson P, Smith P, Blake A, Stewart D. Different polyphenolic components of soft fruits inhibit alpha-amylase and alpha-glucosidase. J Agric Food Chem. 2005;53(7):2760-6.

20. Oboh G, Ademosun AO, Ademiluyi AO, Omojokun OS, Nwanna EE, Longe KO. In vitro studies on the antioxidant property and inhibition of alpha-amylase, alpha-glucosidase and angiotensin I-converting enzyme by polyphenol-rich extracts from cocoa (Theobroma cacao) bean. Patholog Res Int. 2014;549287. doi:10.1155/2014/549287.

21. Oboh G, Ademiluyi AO, Akinyemi AJ, HenleT, Saliu JA, Schwarzenbolz U. Inhibitory effect of polyphenol-rich extracts of jute leaf (Corchorus olitorius) on key enzyme linked to type 2 diabetes ( $\alpha$-amylase and $\alpha$-glucosidase) and hypertension (angiotensin I converting) in vitro. J Funct Foods. 2012;4(2):450-8.

22. Takagi S, Miura T, Ishibashi C, Kawata T, Ishihara E, GuY, et al. Effect of corosolic acid on the hydrolysis of disaccharides. J Nutr Sci Vitaminol (Tokyo). 2008;54(3):266-8.

23. Franco OL, Rigden DJ, Melo FR, Grossi-De-Sa MF. Plant alpha-amylase inhibitors and their interaction with insect alpha-amylases. Eur $\mathrm{J}$ Biochem. 2002;269(2):397-412.

24. Alkazaz M, Desseaux V, Marchis MG, Payan F, Forest E, Santimone M. The mechanism of porcine pancreatic alpha-amylase. Eur J Biochem. 1996;796:787-96.

25. Desseaux V, Koukiekolo R, Moreau Y, Santimone M, Marchis MG. Mechanism of porcine pancreatic $\alpha$-amylase (PPA): inhibition of amylose and maltopentaose hydrolysis by various inhibitors. Biologica. 2002;11:163-70.

26. Zhang B, Li X, Sun W, Xing Y, Xiu Z, Zhuang C, et al. Dietary flavonoids and acarbose synergistically inhibit $\alpha$-glucosidase and lower postprandial blood glucose. J Agric Food Chem. 2017;65(38):8319-30.

27. Keawpradub N, Purintrapiban J. Upregulation of glucose uptake in L8 myotubes by the extract from Lagerstroemia speciosa: a possible mechanism of action. Maejo Int J Sci Technol. 2009;3(3):472-85

28. Park MY, Lee KS, Sung MK. Effects of dietary mulberry, Korean red ginseng and banaba on glucose homeostasis in relation to PPAR-alpha, PPAR-gamma and LPL mRNA expressions. Life Sci. 2005;77(26):3344-54.

\section{GRAPHICAL ABSTRACT}

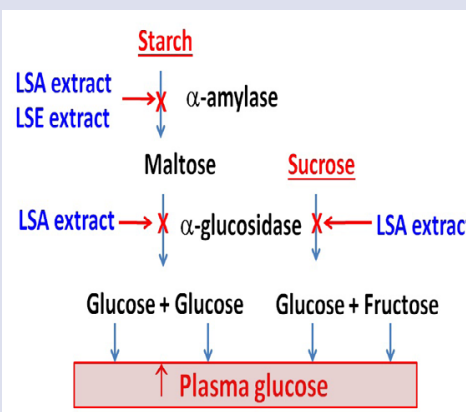

- LSA extract = Lagerstroemia speciosa aqueous leaf extract - LSE extract $=$ = Lagerstroemia speciosa ethanolic leaf extract

\section{SUMMARY}

- The LSA extract possessed the inhibitory actions against $\alpha$-amylase and $\alpha$-glucosidase enzymes with the $I_{50}$ of $1.21 \pm 0.16$ and $49.71 \pm 0.86 \mu \mathrm{g} / \mathrm{mL}$, respectively.

- The LSE extract significantly inhibited $\alpha$-amylase activity $\left(\mathrm{IC}_{50}\right.$ of $22.21 \pm 4.00$ $\mu \mathrm{g} / \mathrm{mL}$ ) with no apparent inhibition toward $\alpha$-glucosidase activity.

- The extracts performed their inhibitions against the carbohydrate-digesting enzymes in the mixed inhibition manner.

- These in vitro carbohydrate-digesting enzyme inhibitions partly justified the mechanisms of action of Lagerstroemia speciosa (L.) Pers. leaves for the treatment of diabetes mellitus in folk medicine

Cite this article: Khunawattanakul W, Boonma P, Kampetch R, Jaruchotikamol A, Cushnie B, Rattanakiat S, Pulbutr P. Inhibitory Actions of Lagerstroemia speciosa (L.) Pers. Aqueous and Ethanolic Leaf Extracts against Carbohydrate-digesting Enzymes. Pharmacog J. 2018;10(6)Suppl:s113-s118. 